\title{
Analogy of Non-Destructive Tests for the Detection of Defectologies in Aluminium Cylinder Heads
}

\author{
Stephen S. Valencia ${ }^{1, a}$, Lily C. Galárraga ${ }^{1, b}$, \\ Héctor C. Terán ${ }^{1, c}$ and Oscar Arteaga ${ }^{1, d}$ \\ ${ }^{1}$ Universidad de las Fuerzas Armadas - ESPE, Sangolquí, Ecuador \\ assvalencia@espe.edu.ec, blcgalarraga@espe.edu.ec, \\ chcteran@espe.edu.ec, dobartega@espe.edu.ec
}

\begin{abstract}
Palabras clave: Culatas de automovil, Defectologías, END, Pruebas de Corrientes de Eddy
\end{abstract}
\begin{abstract}
The present experimental study proposes an alternative for diagnostic methods and quality control in cylinder head defectology. The composition of the material is characterized by spectrometry, obtaining an approximation of aluminum 2117. For the detection of defectologies, nondestructive tests (NDT) are carried out, applicable to cylinder heads such as: visual inspection (VT) under conditions of standard EN 13018, penetrating inks (PT) visible according to ASTM E 165-02 and others not yet included in the vehicle fleet; infrared thermography (IRT) with equipment specifications under ISO 18434 - 1, ultrasound (UT) based on standard EN 583 for the use of the equipment and Eddy currents (ECT) conforming standard ISO 15548, the analysis is carried out on the flat surface of the cylinder head, combustion chamber, valve seats and intake - exhaust ports, the different defects found are: cracks, fissures, discontinuities and pitting, showing longitudinal dimensions from $0,8[\mathrm{~mm}]$. To determine the reliability of results, an analogy is made of the tests mentioned in the same defect, the method with the greatest scope is Eddy currents as it has more inspection coverage with respect to the remaining tests; the simulation of computer-aided engineering CAE of the defect is performed, applying an AC magnetic analysis to identify the flux density, current density and visualize how the Eddy currents act in the cylinder head. After this research, artificial intelligence will be used as a complementary diagnosis, to predict defectologies not perceived by the human eye and to obtain a better analysis of defectologies in cylinder heads.
\end{abstract}

\section{Introduction}

For the fabrication of light-vehicle cylinder heads, light aluminium alloys are used by means of a casting process [1], these alloys are used for their low weight, better heat dissipation, low density and excellent thermal conductivity [2], the cylinder head is subjected to high mechanical and thermal stresses during operation, causing fractures such as: cracks, fissures, discontinuities, impurities, roughness and pitting due to corrosion, fatigue and caloric performance [3-6]; conventional nondestructive tests are used for the detection of these defects, which allow the material to be evaluated without the need to damage or cause alterations in the physical or chemical state, in order to detect imperfection [7].

In the automotive industry, traditional methods such as pressure tester are used [8] and to a lesser extent penetrating inks, to detect cracks or fissures in cylinder heads, non-conventional NDTs such as ultrasound, infrared thermography and Eddy currents are applied to metals for instant and detailed evaluation; Eddy currents are currently used in the industrial field, for aeronautical, petrochemical and nuclear tests [9]; being efficient inspection and defect detection methods, it is important to introduce the vehicle fleet, for the diagnosis and quality control of automotives superficial defectologies and specifically of this emitted in cylinder heads.

\section{Material Characterization}

For the analogy of non-destructive testing, the cylinder head material is characterized, based on standard ASTM E1085 - 16 by means X-ray fluorescence spectrometry by wavelength dispersive energy with the equipment OLYMPUS XRF portable Delta, in the quantitative analysis the 
approximation of an aluminium 2117 alloy was obtained, which presents $96.64 \%$ light elements (LE) representing aluminum $(\mathrm{Al}), 2.55 \%$ Copper $(\mathrm{Cu})$, the difference consists of several elements: $\mathrm{Fe}, \mathrm{Mn}$, $\mathrm{Zn}, \mathrm{Pb}, \mathrm{Ni}, \mathrm{Zr}$ and its structure is based on a casting process.

\section{Methods and Test}

The main defectologies presented by automobile cylinder heads can be identified by nondestructive tests, specifically in the cylinder heads, visual inspection tests are used for their easy inspection and quick diagnosis; penetrating inks are used to evidence defects on surfaces of metals and non-porous materials, the non-conventional methods used for the evaluation are: ultrasound for its high penetration capacity and fast scanning; infrared thermography by producing images through thermal radiation produced by objects in the fault areas and Eddy currents, detects surface discontinuities when applied to conductive metals. With the use of these tests it is possible to detect faults in the functionality of the cylinder head, detailed in Table 1.

Table 1. Non-destructive tests applied to the detection of defectologies in the cylinder head.

\begin{tabular}{|c|c|c|c|c|}
\hline $\begin{array}{l}\text { Non- } \\
\text { destructive } \\
\text { testing } \\
\end{array}$ & Principle & Standards & $\begin{array}{l}\text { Equipment } \\
\text { and } \\
\text { materials } \\
\end{array}$ & Guidelines \\
\hline $\begin{array}{l}\text { Visual } \\
\text { inspection } \\
\text { VT }\end{array}$ & $\begin{array}{l}\text { Surface observation } \\
\text { of the object to } \\
\text { evaluate } \\
\text { discontinuities. }\end{array}$ & $\begin{array}{l}\text { EN } 13018 \\
\text { ASME } \\
\text { BPVC.V }\end{array}$ & Human eye & $\begin{array}{l}\text { - Surface luminance. } \\
\text { - Place the eye less than } \\
600[\mathrm{~mm}] \text { from the surface. }\end{array}$ \\
\hline $\begin{array}{l}\text { Penetrating } \\
\text { inks } \\
\text { PT }\end{array}$ & $\begin{array}{l}\text { Apply penetrating } \\
\text { liquid to the } \\
\text { surface, which will } \\
\text { reveal defects due } \\
\text { to the phenomenon } \\
\text { of capillarity. }\end{array}$ & $\begin{array}{l}\text { ASTM E165- } \\
02 \\
\text { ASTM E1417 } \\
\text { ISO } 3452 \\
\text { ASME } \\
\text { BPVC.V }\end{array}$ & $\begin{array}{c}\text { Penetrant } \\
\text { Kit }\end{array}$ & $\begin{array}{l}\text { - The surface must be } \\
\text { between } 40 \text { and } 125^{\circ} \mathrm{F}(4 \\
\left.\text { and } 52^{\circ} \mathrm{C}\right) \text {. } \\
\text { - Inspect with a minimum } \\
\text { luminance of } 5001 \mathrm{x} \text {. } \\
\text { - Pre-cleaning, drying and } \\
\text { penetrant application } \\
\text { - Removal of penetrant and } \\
\text { application of developer }\end{array}$ \\
\hline $\begin{array}{l}\text { Infrared } \\
\text { thermography } \\
\text { IRT }\end{array}$ & $\begin{array}{l}\text { It maps surface } \\
\text { temperatures as a } \\
\text { function of the } \\
\text { infrared radiation } \\
\text { emitted by an } \\
\text { object as heat flows } \\
\text { through, to or from } \\
\text { that object. }\end{array}$ & ISO & $\begin{array}{c}\text { FLUKE } \\
\text { TiR32 }\end{array}$ & $\begin{array}{l}\text {-Dry surface. } \\
\text {-Calibrated IRT } \\
\text { quantitative chamber. } \\
\text {-Natural or induced means } \\
\text { of heating or cooling the } \\
\text { target at least } 20^{\circ} \mathrm{C} \text { above } \\
\text { or below the apparent } \\
\text { temperature. }\end{array}$ \\
\hline $\begin{array}{l}\text { Ultrasound } \\
\text { UT }\end{array}$ & $\begin{array}{l}\text { Acoustic } \\
\text { impedance, which } \\
\text { manifests itself as } \\
\text { the product of the } \\
\text { maximum speed of } \\
\text { sound propagation } \\
\text { between the density } \\
\text { of the material. }\end{array}$ & $\begin{array}{l}\text { EN } 12668 \\
\text { EN } 583\end{array}$ & $\begin{array}{l}\text { Olympus } \\
\text { EPOCH } \\
1000 \mathrm{i}\end{array}$ & $\begin{array}{l}\text { - In metallic materials } \\
\text { equal or superior to } 10 \\
\text { [mm] of thickness. } \\
\text { - Minimum frequency } \\
\text { range } 1 \text { to } 6[\mathrm{MHz}] \text {. } \\
\text { - Gain calibrated to a } \\
\text { minimum of } 2 \mathrm{~dB} \text {. }\end{array}$ \\
\hline $\begin{array}{c}\text { Eddy Current } \\
\text { Testing } \\
\text { ECT } \\
\end{array}$ & $\begin{array}{l}\text { Creates a magnetic } \\
\text { field, where defects } \\
\text { cause anomalies in } \\
\text { the flow of energy }\end{array}$ & $\begin{array}{l}\text { ISO } 15548 \\
\text { ASME } \\
\text { BPVC.V }\end{array}$ & $\begin{array}{l}\text { Olympus } \\
\text { Nortec } \\
2000 \mathrm{D}+\end{array}$ & $\begin{array}{l}\text { - The frequency is chosen } \\
\text { according to the material } \\
\text { (conductivity, } \\
\text { permeability) }\end{array}$ \\
\hline
\end{tabular}




\begin{tabular}{|l|l|l|l|}
\hline $\begin{array}{l}\text { and these are } \\
\text { detected externally. }\end{array}$ & & $\begin{array}{l}\text {-Adjust the angle } \\
\text { - Use of probes for every } \\
\text { analysis } \\
- \text { Scanning speed does not } \\
\text { exceed } 100[\mathrm{~mm} / \mathrm{s}] .\end{array}$ \\
\hline
\end{tabular}

\section{Visual Testing (VT)}

The direct visual inspection test examines large defectologies on the surface of the cylinder head at $45^{\circ}$ and $200[\mathrm{~mm}]$ distance between the human eye and the specimen. According to Eq. 1, the refractive index $(\mathrm{n})$ is calculated, resulting $1.32[\mathrm{~m} / \mathrm{s}]$ with a vacuum speed of light (Vs) of 299792452 $[\mathrm{m} / \mathrm{s}]$, submitted to the speed of light of the test $(\mathrm{Vm})$ of $227000[\mathrm{Km} / \mathrm{s}]$. This in daylight with a luminance higher than 1000 luxes, as established by ASME BPVC.V - Article 9.

$$
n=\frac{V_{s}}{V_{m}}
$$

\section{Penetrant Testing (PT)}

The evaluation was performed based on ASTM E 165-02, Type II, with visible penetrants, method B - solvent removable. The temperature is $19,1\left[{ }^{\circ} \mathrm{C}\right]$. As the aluminium cylinder head is 2117 , the penetration and revelation times to obtain an appropriate capillarity suggest 5 and 10 minutes respectively. For the removal of the penetrant liquid apply the cleaner with the wipping technique.

Fig. 1 a) Cylinder to be evaluated, b) Test of penetrating inks

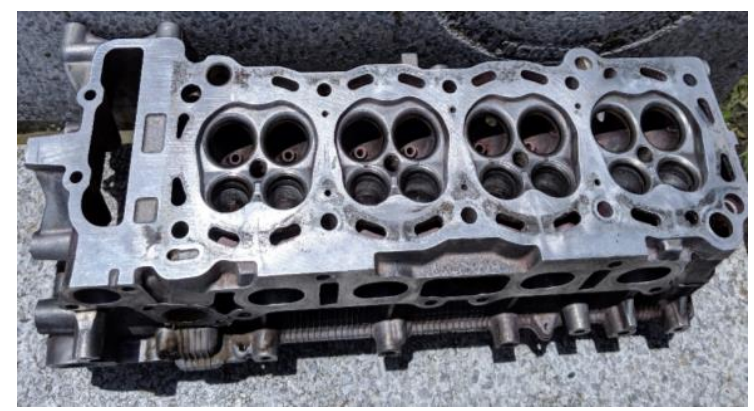

(a)

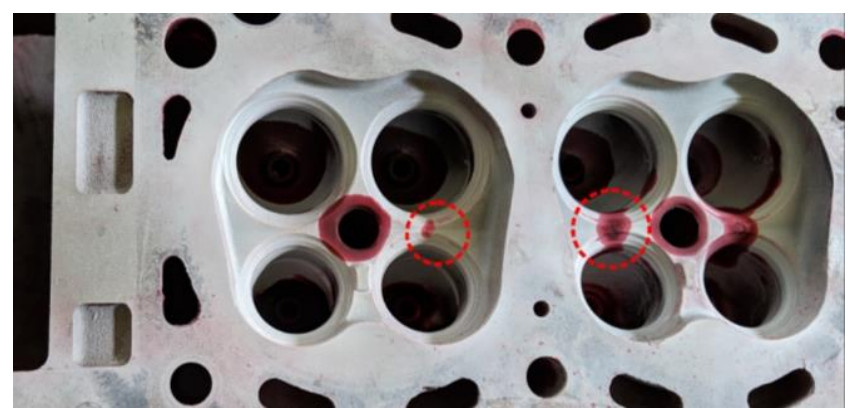

(b)

Fig. 1(a) Cylinder head; (b) Tests applied to the cylinder head.

\section{Infrared Thermography (IRT)}

The Step Heating technique was used, the cylinder head is heated at low power for one minute until reaching a temperature of $40\left[{ }^{\circ} \mathrm{C}\right]$ to monitor the cooling of the cylinder head and analyze the defects that are found, are displayed in small contrast changes. With the IRT camera and the Smart View software, the different temperatures present in the captured image are verified.

In Fig. 2, shows a) accentuated defectology in the union of intake - exhaust seats and in intake ducts where small marks are perceived indicating another type of defect, (b) contrast difference located in the valve seat.

To determine the radiated energy in the cylinder head when heated apply Eq. 2, use Stefan Boltzman's constant $\theta=5,6697 \times 10^{-6}\left[\mathrm{w} / \mathrm{m}^{2} \mathrm{~K}^{4}\right]$, at a surface temperature $\mathrm{T}=307,15\left[{ }^{\circ} \mathrm{K}\right.$ ], obtaining a radiation of $50461,73\left[\mathrm{w} / \mathrm{m}^{2}\right]$.

$$
I=\theta T^{4}
$$




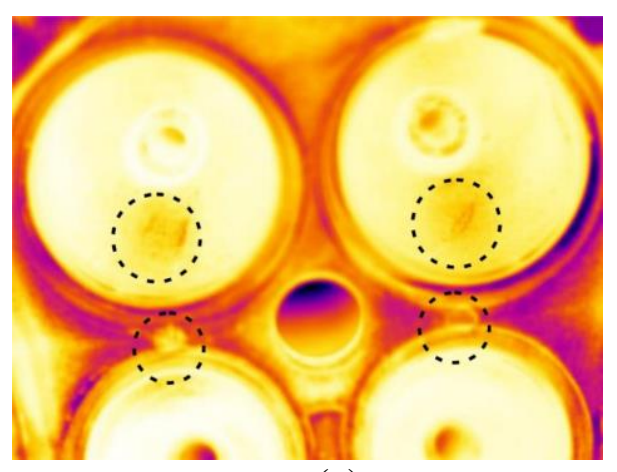

(a)

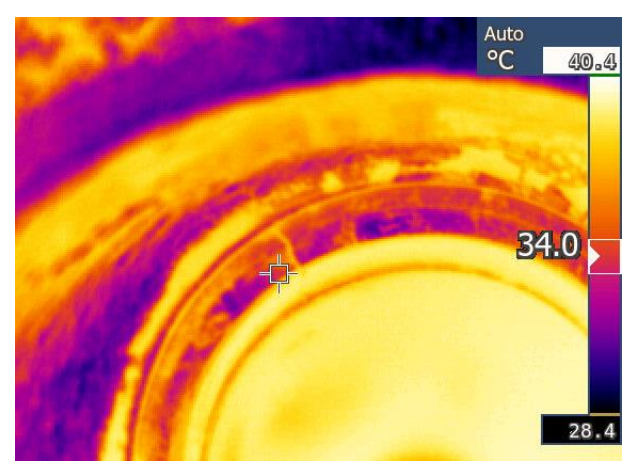

(b)

Fig. 2 Infrared thermography test applied to the combustion chamber.

\section{Eddy current testing (ECT)}

Before the test, the equipment is calibrated when inspecting the cylinder head, the frequency is established and the gains are varied to obtain a better visualization of the curves, depending on the area to inspect and the probe that examines.

Probes are used:

a) $500[\mathrm{KHz}]-1[\mathrm{MHz}]$ : Frequency of $800[\mathrm{KHz}], 55^{\circ}$ angle and $52.4 \mathrm{~dB}$ and $55.0 \mathrm{~dB}$ gain, horizontal and vertical, respectively, to determine the curve of a valve seat defect.
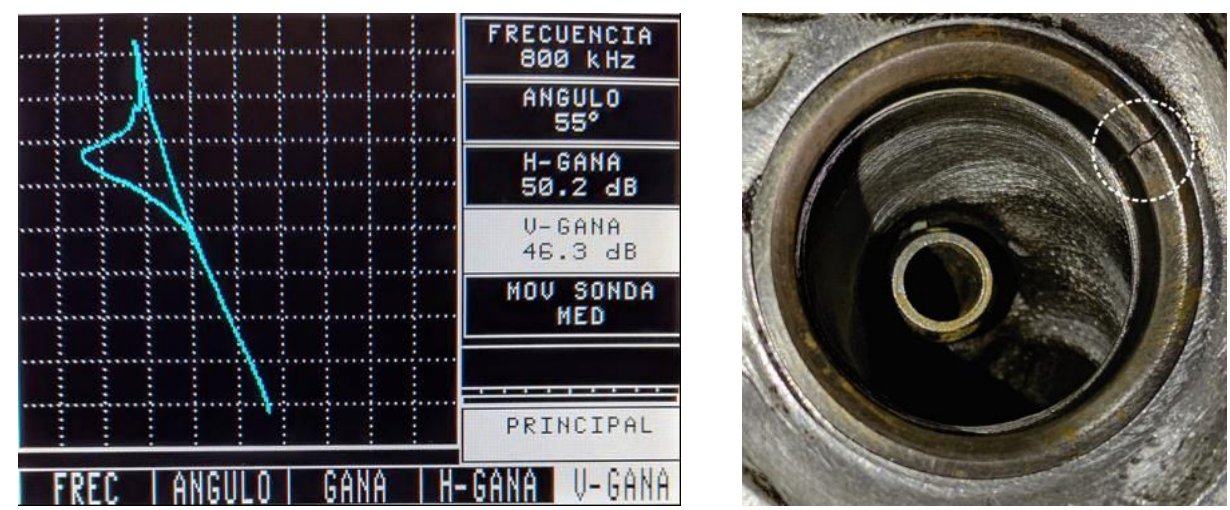

Fig. 3 Eddy currents applied to defectology in valve seat.

b) $100[\mathrm{kHz}]-500[\mathrm{kHz}]$ : The valve seats, intake and exhaust ducts are inspected, with a frequency of $300[\mathrm{kHz}]$, an angle of $55^{\circ}$, gains of $62.2 \mathrm{~dB}$ and $51.2 \mathrm{~dB}$, horizontal and vertical respectively, the curve is identified in the shape of an ellipse.
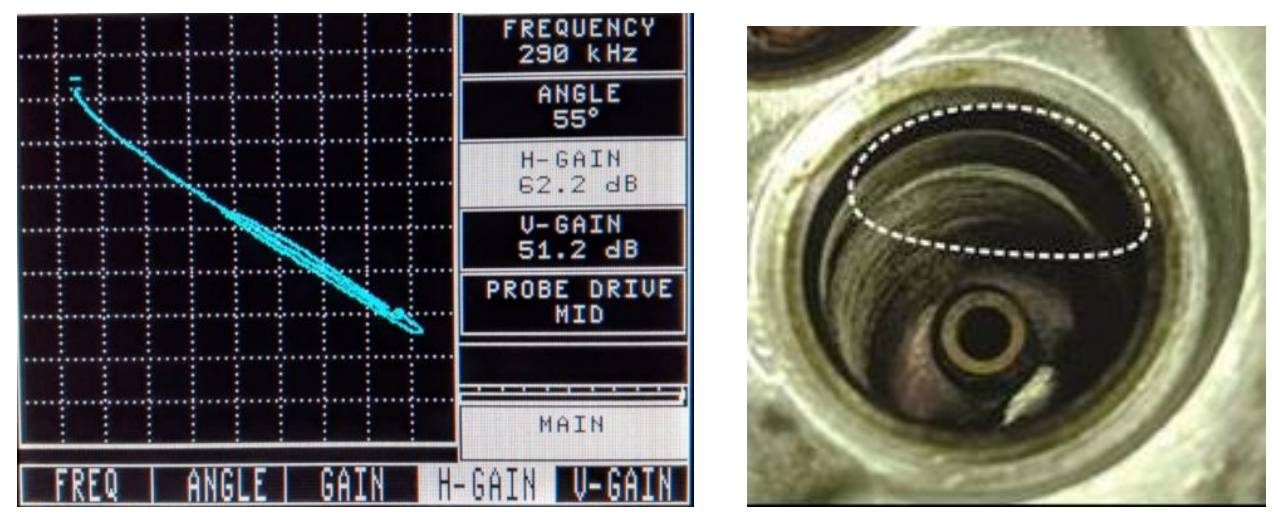

Fig. 4 Eddy currents applied in intake - exhaust ducts. 


\section{Ultrasound Testing - Phased Array mode (UT - PA)}

With the Olympus Epoch 1000i, phased array mode and straight probe, the aluminum cylinder head is analyzed, the sound propagation speed of $6320[\mathrm{~m} / \mathrm{s}]$ is set to identify defects on the flat face of the cylinder head. Fig. 5 shows a superficial imperfection with a range of 11.8 and a gain of 4.58 $\mathrm{dB}$, angle $-30^{\circ}$ to 30 .

Eq. 3, defines the velocity of wavelength $V_{L}$ equivalent to $5091,75[\mathrm{~m} / \mathrm{s}]$, the radical of Young's module $\left(\right.$ E) for aluminum7 $\times 10^{10}\left[\mathrm{~N} / \mathrm{m}^{2}\right]$, divided for aluminum density $(\rho)$ of $2700\left[\mathrm{Kg} / \mathrm{m}^{3}\right]$.

$$
V_{L}=\sqrt{\frac{E}{\rho}}
$$

The shear wave velocity $\left(V_{S}\right)$ is calculated with the root of the shear modulus $(G) 2,5 \times$ $10^{10}\left[\mathrm{~N} / \mathrm{m}^{2}\right]$ over the density of the material $(\rho)$ de $2700\left[\mathrm{Kg} / \mathrm{m}^{3}\right]$, the resultant of Eq. 4, is 3042,90 $[\mathrm{m} / \mathrm{s}]$.

$$
V_{S}=\sqrt{\frac{G}{\rho}}
$$

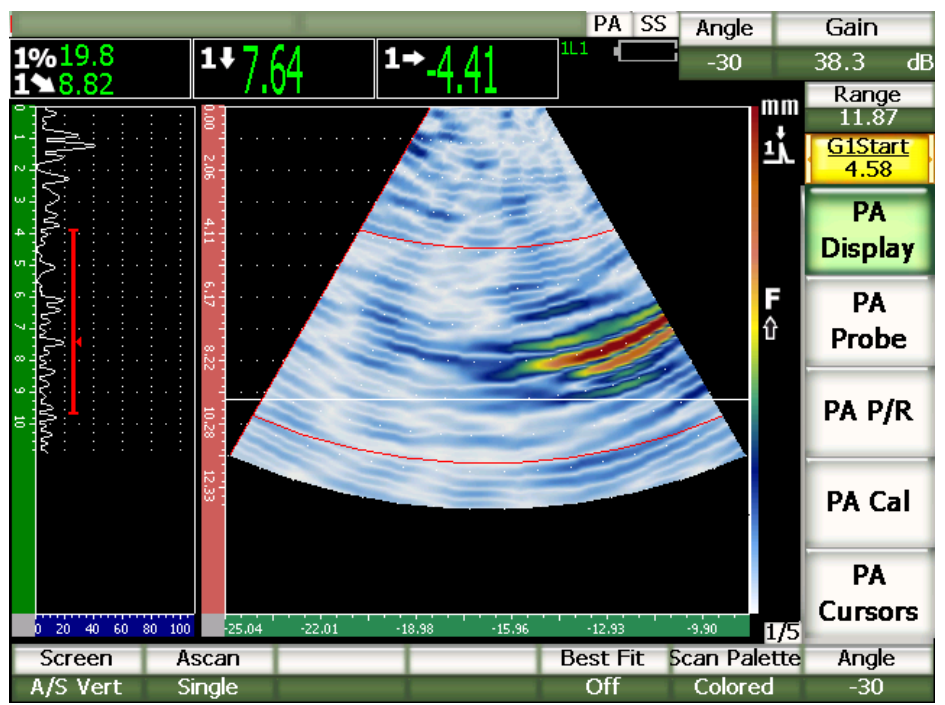

Fig 5. Analysis of the surface of the cylinder head applying Ultrasound Mode Phased Array.

\section{Results Analysis}

Fig. 6 summarizes the lengths of the types of imperfections locate in the different sectioned parts of the cylinder head, according to the coverage of each inspection method and penetration reach presented by non-conventional tests. 


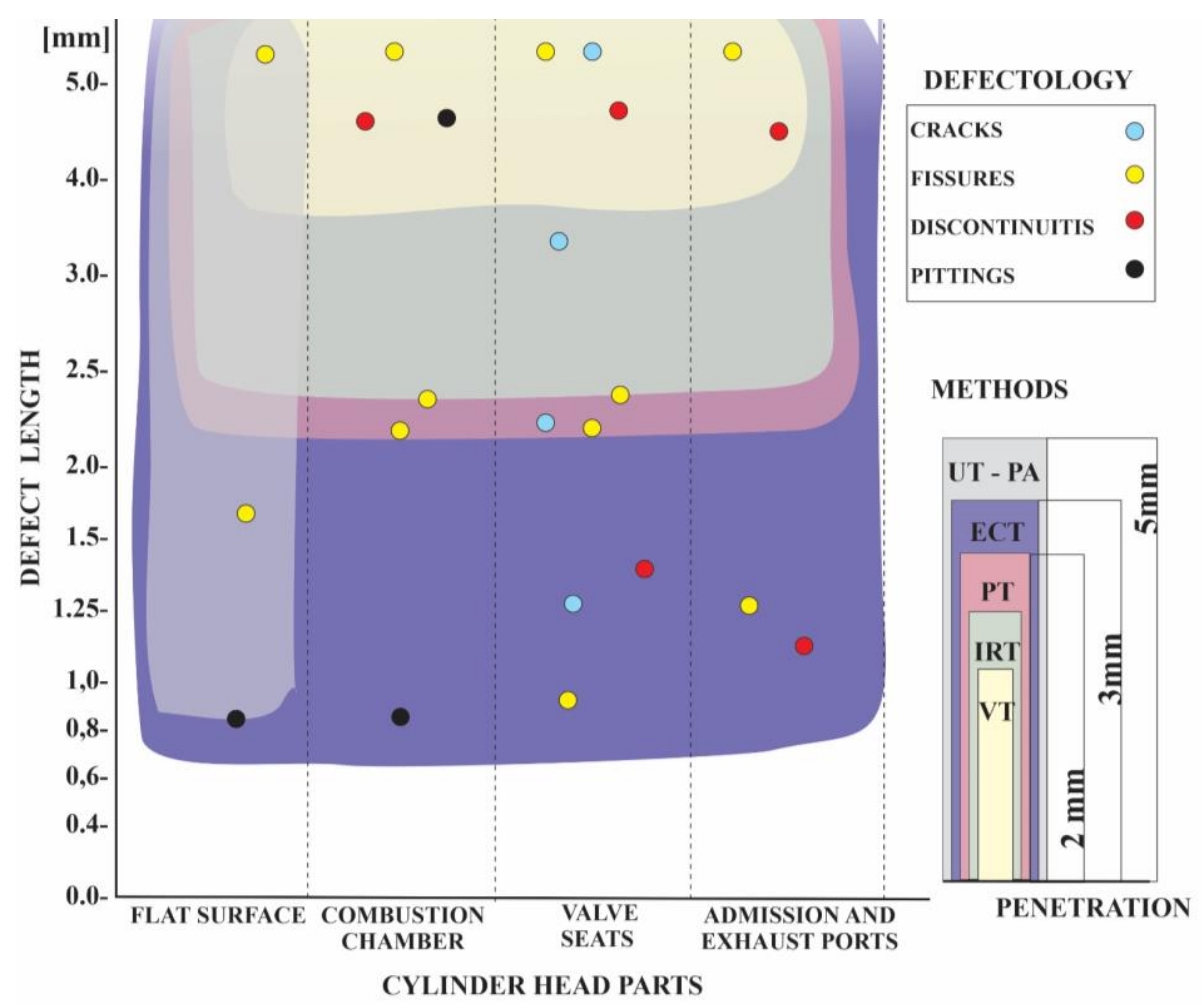

Fig. 6 Analogy of non-destructive tests according to failure, length and penetration.

In the different parts of the cylinder head that sectionalizes the study, the location of the four types of defectologies is determined and the effectiveness of the five methods for diagnosis is compared.

On the surface of the cylinder head the visual inspection method is utilized, found fissures from $4.8[\mathrm{~mm}]$, at the same time ultrasound and Eddy currents for minimum pittings of 0.8 [mm].

In the combustion chamber, a variety of defectologies were found internally, it is determined that the most efficient is the Eddy current test detecting pittings less than 1 [mm], fissures from 2 [mm] onwards are visible with penetrating inks and discontinuities of $4[\mathrm{~mm}]$ provoked by valve shock.

In the valve seats, a greater inspection coverage is achieved with the methods used, as they are the most exposed to mechanical stresses, provoking cracking from $1.2[\mathrm{~mm}]$, fissures 0.9 [mm] and discontinuities of $1.3[\mathrm{~mm}]$ in the material.

In the intake and exhaust ducts is produce fissures and discontinuities of 1.2 [mm], which are efficiently detected with Eddy currents, infrared thermography and visual inspection depending on their size, being Eddy the test that demonstrates to have a better reach of inspection.

To validate the findings by performing the analogy of the different non-destructive tests applied to the cylinder head in the same defect are shown in Fig. 7, (a) visual inspection, it is not possible to see imperfections between seats, (b) inspection by penetrating liquids, a red mark is visualized due to the capillarity of the penetrant on the developer, indicates a fissure, (c) infrared thermography, fissure is identified in different contrast and (d) Eddy currents, an alteration in the lift off line is identified, which represents a fissure in the curve obtained. The ultrasound test was not applicable in the same area because of cylinder head geometry and phased array probe types. 


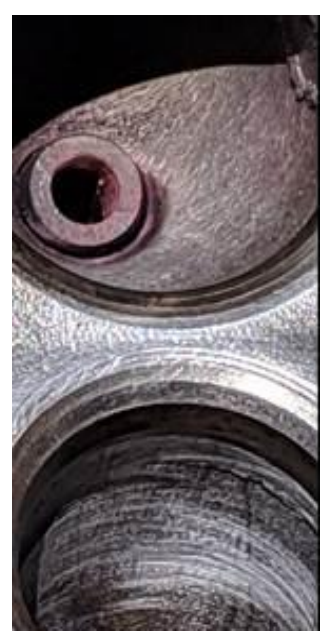

(a) VT

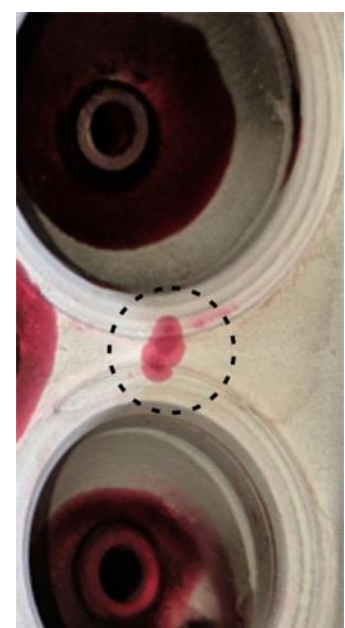

(b) PT

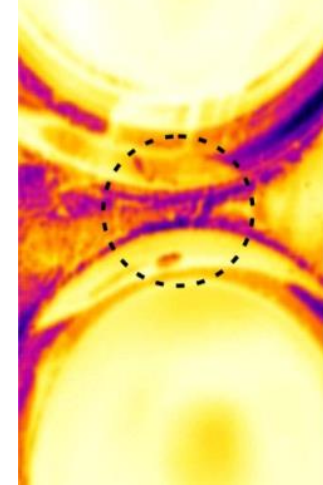

(c) TIR

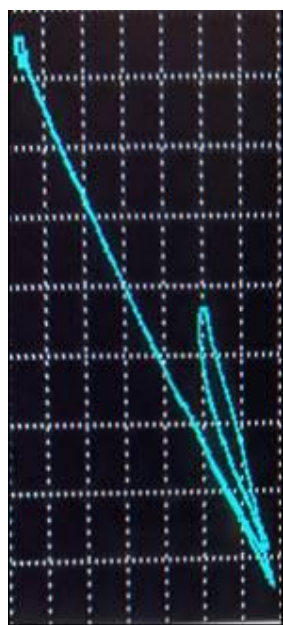

(d) ECT

Fig. 7 Analogy of non-destructive testing (NDT) applied to a fissure in the combustion chamber.

\section{Simulation}

Previous to the simulation the penetration depth is calculated Eq. 6, to the aluminum cylinder head 2117 to be analyzed, with an electrical conductivity $\sigma=3.526 \times 10^{7}[\mathrm{~S} / \mathrm{m}]$, magnetic permeability of free space $\mu=\mu_{0}=4 p \times 10^{-7}[\mathrm{H} / \mathrm{m}]$, an excitation frequency of $200[\mathrm{kHz}]$ is applied; which determines the penetration depth $0.19[\mathrm{~mm}]$, being inversely proportional to the frequency, the higher the frequency the lower the skin depth.

$$
\delta=\frac{1}{\sqrt{\left(\pi f \mu_{0} \sigma\right)}}
$$

A CAD model of the cylinder head has been made applying Eddy currents, simulated in EMS for SW, using AC magnetic analysis, with geometric parameters of a fissure with width, depth and length of: $1[\mathrm{~mm}], 1[\mathrm{~mm}]$ and $5[\mathrm{~mm}]$ respectively.

Means are applied to all the elements that interfere with the study; the copper coil with an electrical conductivity of $58,100 \mathrm{e}+6[\mathrm{~S} / \mathrm{m}]$, the cylinder head surface of aluminium with an electrical conductivity of $3.06 \mathrm{e}+07[\mathrm{~S} / \mathrm{m}]$ and the surrounding air of the cylinder head and coil of 0 . The properties of the wound coil; 170 number of turns, and current magnitude of 30 [mA].

Fig. 8 a) shows the coil of an Eddy current probe at $200[\mathrm{kHz}]$ operating on the cylinder head, b) shows the density of the magnetic flux generated by the coil on the fissure, in interaction with the cylinder head, in a global range between $5.213878 \mathrm{e}-002$ and $8.19322169 \mathrm{e}-02$, with coil lift-off of $0.13[\mathrm{~mm}]$.

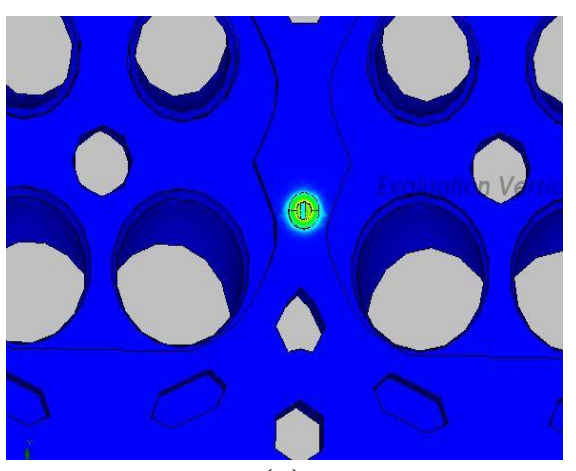

(a)

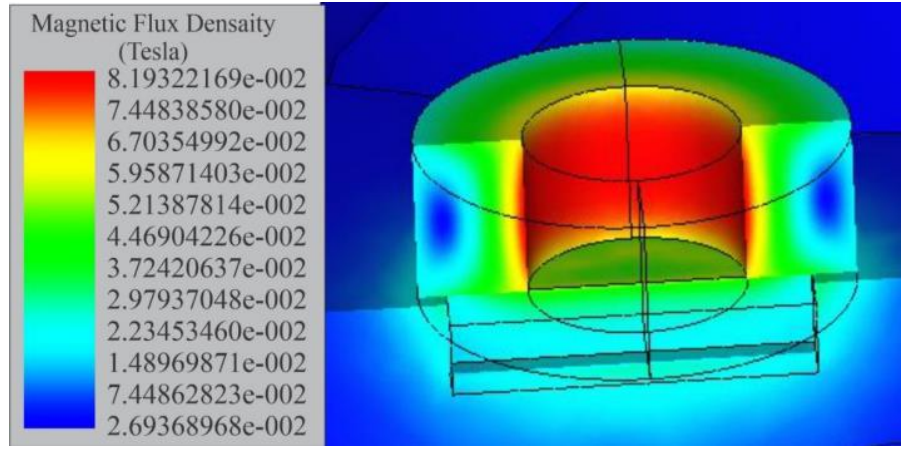

(b)

Fig. 8 CAE simulation of Eddy currents applied to a cylinder head. 


\section{Conclusions}

NDT results show in Visual Inspection detects defects from 4.5 [mm], Infrared Thermography covers a range from $2.5[\mathrm{~mm}]$ of length, Penetrating Inks reveals failures from $2[\mathrm{~mm}]$ onwards and does not detect all cases of defects, Ultrasound despite having a greater range of penetration, is limited to evaluating the surface in the cylinder head.

According to the analogy made, the Eddy current test is determined to have a higher efficiency, having a greater scope of inspection than the others, detecting the four types of defectology found in the cylinder head since a pittings $0.8[\mathrm{~mm}]$ in length, fissures of $0.9[\mathrm{~mm}]$, cracks and discontinuities from $1.2[\mathrm{~mm}]$.

In the ECT test specifically, the optimum frequencies for defectology inspection in aluminium cylinder heads are $800[\mathrm{kHz}]$ and $200[\mathrm{kHz}]$ with a $55^{\circ}$ angle to detect cracks, fissures, pittings and discontinuities in the combustion chamber and intake - exhaust ducts.

Eddy Currents present an inspection range since $0.8[\mathrm{~mm}]$ and is the only inspection method that allows the complete cylinder head to be evaluated; is determined ECT, as a new method of diagnosis and quality control in the service life of alloy cylinder heads.

The study will be complemented with the implementation of artificial intelligence (AI) with learn machine SVM, to predict defectologies that are not perceived by the human eye and to obtain a better diagnosis and quality control in the useful life of cast aluminum alloy cylinder heads

\section{References}

[1] I. Nova, J. Machuta, Microstructure of aluminium alloys casting intended for cyclical thermal stress, (2016).

[2] Y. Birol, A. A. Ebrinç, Critical material issues in cast aluminium cylinder heads, (2008).

[3] C. Kliemt, F. Wilhelm, J. Hammer, Lifetime Improvement of AlSi6Cu4 Cylinder Head Alloy, Adv. Mater. Res. 891-892 (2014) 1627-1632.

[4] E. Tillová, M. Chalupová, L. Kuchariková, Quality control of cylinder head casting, Production Eng. Arc. 14 (2017) 3-6.

[5] R. Fuoco, M. Moreira, Fatigue Cracks in Aluminum Cylinder Heads for Diesel Engines, Int. J. Metalcasting, 4(4) (2010) 19-32.

[6] Y. Birol, A. A. Ebrinc, Fatigue failures in low pressure die cast AlSi10Mg cylinder heads, Int. J. Cast Metals Res. 21(6) (2013) 408-415.

[7] ASNT, The American Society for Nondestructive testing, Available: https://www.asnt.org/MinorSiteSections/AboutASNT/Intro-to-NDT.aspx.

[8] T\&L Engineering LTD, Pressure testing in Elstow, Available: https://vintageengine.net/pressure-testing/?cn-reloaded $=1$.

[9] J. G. Martín, J. G. Gil, E. Vázquez-Sánchez, Non-Destructive Techniques Based on Eddy Current Testing, Sensors, 11 (2011) 2525-2565. 